\title{
Genetically Diverse Coronaviruses in Captive Bird Populations in a Brazilian Zoological Park
}

\author{
Tereza C. Cardoso,' Maria Cecília B. Teixeira, Deriane E. Gomes, and Antônio José Jerez²
}

\begin{abstract}
This study aimed to investigate the occurrence of coronaviruses (CoVs) in captive birds placed inside a zoological park in Brazil. The role of captive birds in the epidemiology of CoVs in the tropics is poorly understood. A total of $25(n=25)$ different species were tested for viral RNA using individual fecal samples collected from healthy birds. Reverse transcription-polymerase chain reaction targeting the $3^{\prime}$ untranslated region was used to detect CoV RNA, and positive samples were submitted for sequence analysis. The phylogenetic search revealed nine mutations in the black shouldered peafowl (Pavus cristatus) CoV sequence, which clustered separately from samples previously described in England. This is the first report on the detection of the CoV genome in captive birds in Brazil.
\end{abstract}

Key Words: Brazil—Captive birds—Coronavirus—Zoo parks.

\section{Introduction}

$\mathbf{T}$ He OUTBREAKS OF HIGHLY PATHOGENIC avian influenza viruses around the globe in the past few years have been devastating for the countries concerned and have created fear in the general population. Similarly, in 2002 the world witnessed the emergence of severe acute respiratory syndrome in Guangdong Province, China, caused by a previously unknown coronavirus (CoV) (Liu 2003). It is likely that additional, yet to be identified CoVs are circulating in domestic birds, especially in tropical countries. The three existing groups of $\mathrm{CoVs}$ were initially distinguished based on the lack of an antigenic relationship between them (Masters 2006). Group $3 \mathrm{CoVs}$, which are genetically similar to infectious bronchitis virus (IBV), have been detected in healthy galliform and nongalliform birds (Cavanagh et al. 2002). Recently, populations of wild birds in northern England were found to have IBV-like RNA in their feces (Hughes et al. 2009). Currently, little information is available about the role of South American bird populations as reservoirs or long-distance vectors of $\mathrm{CoV}$-like viruses.

Viral diseases can cause substantial mortality in both wild and captive bird populations. Brazil is a country with many migrating wild birds, which is likely to facilitate disease transmission from migratory to nonmigratory flocks in zoological parks or on farms. As viral detection and identification techniques become increasingly sophisticated, and as the study of wildlife diseases increases, it is likely that new viruses will be discovered and new diseases will be encountered (Hughes et al. 2009). Therefore, studies of the viral diseases of wild and captive birds are necessary. The latest techniques of molecular epidemiology can help scientists understand how viruses move from species to species and from region to region (Hughes et al. 2009, Jackwood et al. 2010).

The present study demonstrates the molecular detection and characterization of viruses from captive exotic bird populations sampled in São Paulo State Zoological Park in Brazil, which appear to be related to group $3 \mathrm{CoVs}$.

\section{Materials and Methods}

\section{Study design}

Serial cross-sectional surveys of captive wild bird populations, maintained in a zoological park in the city of Bauru (N22 $\left.10^{\prime} \mathrm{S} 49^{\circ} 00^{\prime} \mathrm{W}\right)$, were undertaken in July 2009. Feces were collected from 25 different species of healthy birds (Table 1), placed in virus transport media (Eagle's minimum essential medium supplemented with $10 \%$ fetal calf serum, penicillin, and streptomycin suspension, plus amphotericin B), and frozen at $-80^{\circ} \mathrm{C}$ for individually analysis later. This work was authorized by the Animal Ethics Committee of the São Paulo State University (protocol number 2008/09878-09).

\footnotetext{
${ }^{1}$ Laboratory of Animal Virology, UNESP, School of Veterinary Medicine, University of São Paulo State, Araçatuba, Brazil

${ }^{2}$ Coronavirus Research Group, School of Veterinary Medicine, University of São Paulo, São Paulo, Brazil.
} 
Table 1. Captive Bird Species from Whom Fecal Samples Were Collected and Screened for Coronavirus RNA

\begin{tabular}{|c|c|c|c|}
\hline Common name & Latin name & Age & Positive/total samples \\
\hline Chestnut-bellied heron & Agamia agami & Ad. ${ }^{a}$ & $1 / 20$ \\
\hline Egyptian goose & Alopochen aegyptiacus & Ad. & $0 / 20$ \\
\hline Amazon parrot & Amazona estiva & Juv. ${ }^{b}$ & $0 / 5$ \\
\hline Blue-front parrot & Amazona vinacea & Ad. & $0 / 5$ \\
\hline Bar-headed goose & Anser indicus & Juv. & $0 / 5$ \\
\hline Emperor penguin & Aptenodytes patagonicus & Ad. & $1 / 2$ \\
\hline Cattle egret & Bubulcus íbis & Juv. & $0 / 0$ \\
\hline Red-legged seriema & Cariama cristata & Ad. & $0 / 4$ \\
\hline Kelp gull & Larus atlanticus & Ad. & $0 / 2$ \\
\hline Silver pheasant & Lophura nycthemera & Ad. & $0 / 1$ \\
\hline Tawny-bellied screech-owl & Megascops watsonii & Ad. & $0 / 12$ \\
\hline Red crested cardinal & Paroaria coronata & Juv. & $0 / 2$ \\
\hline Black shouldered peafowl & Pavus cristatus & Ad. & $2 / 5$ \\
\hline Indo-Chinese Green peafowl & Pavus muticus & Ad. & $0 / 14$ \\
\hline Ring necked pheasant & Pavus torquatus & Ad. & $0 / 1$ \\
\hline Dusky legged guan & Penelope obscura & Ad. & $0 / 1$ \\
\hline Rusted margined guan & Penelope supercilliaris & Ad. & $1 / 2$ \\
\hline Pheasant & Phasianus colchicus & Ad. & $0 / 12$ \\
\hline Greater flamingo & Phoenicopterus rubber & Ad. & $0 / 9$ \\
\hline Black-fronted pippin-guan & Pipile jacutinga & Juv. & $0 / 8$ \\
\hline Caraca cheryway & Plyborus plancus & Ad. & $0 / 23$ \\
\hline American purple gallinule & Porhyrula matinica & Ad. & $2 / 3$ \\
\hline Saffron toucanet & Pteroglossus bailloni & Ad. & $0 / 16$ \\
\hline Lettered aracari & Pteropglossus inscriptus & Juv. & $0 / 12$ \\
\hline Toco toucan & Ramphastos toco & Ad. & $0 / 10$ \\
\hline Channel-billed toucan & Ramphastos vitelinus & Juv. & $0 / 10$ \\
\hline Greater rhea & Rhea americana & Ad. & $0 / 10$ \\
\hline Roadside hawks & Rupornis magnirostris & Ad. & $1 / 10$ \\
\hline
\end{tabular}

${ }^{\mathrm{a}} \mathrm{Ad}$. , adult ( $>2$ years).

buv., juvenile ( $<2$ years).

\section{Viral RNA extraction}

Two grams of feces was homogenized in two volumes of Eagle's essential medium (Invitrogen ${ }^{\mathrm{TM}} ; \mathrm{pH} 7.4$ ) and clarified by centrifugation at $3000 \mathrm{~g}$ for $20 \mathrm{~min}$. The supernatant was filtered once through a $0.75-\mu \mathrm{m}$ paper filter (Millipore ${ }^{\mathrm{TM}}$ ) and then twice through a $0.25-\mu \mathrm{m}$ syringe filter (Corning ${ }^{\mathrm{TM}}$ ) as described previously (Teixeira et al. 2007). These suspensions were heated at $100^{\circ} \mathrm{C}$ for $30 \mathrm{~min}$ in a water bath before total RNA extraction was performed. Total RNA was extracted using Trizol $^{\circledR}$ standard protocol, based on guanidinium isothiocyanate and acid-phenol with some modifications (Teixeira et al. 2007). We mixed $200 \mu \mathrm{L}$ of clinical suspension with $500 \mu \mathrm{L}$ of Trizol reagent and incubated for $10 \mathrm{~min}$ at room temperature. After addition of $200 \mu \mathrm{L}$ of chloroform, the reaction was mixed vigorously for $10 \mathrm{~s}$ and centrifuged at $13,000 \mathrm{~g}$ for $10 \mathrm{~min}$. The upper aqueous phase was mixed with an equal volume of cold isopropanol and incubated on ice for $10 \mathrm{~min}$. The total RNA precipitate was pelleted by centrifugation at $13,000 \mathrm{~g}$ for $10 \mathrm{~min}$ and washed with ethanol. The RNA was dissolved in $30 \mu \mathrm{L}$ of diethylpyrocarbonate-treated, sterile, double-distilled water and stored at $-20^{\circ} \mathrm{C}$.

\section{Reverse transcription-polymerase chain reaction}

The primer combination untranslated region (UTR) $11-/$ UTR41+, which corresponds to the conserved region of the IBV $3^{\prime}$ UTR and produces a very sensitive reverse transcriptionpolymerase chain reaction (RT-PCR) result (Adzar et al. 1997, Culver et al. 2006), was used. Before RT-PCR was performed,
RNA was heated for $3 \mathrm{~min}$ at $100^{\circ} \mathrm{C}$, followed by $2 \mathrm{~min}$ at $72^{\circ} \mathrm{C}$, and finally for $2 \mathrm{~min}$ at $50^{\circ} \mathrm{C}$. Optimization of a one-step RT-PCR requires compromises in the concentrations of PCR reagents, particularly the primers used. The RT-PCR was performed following the instructions in the One-Step Superscript III $^{\circledR}$ RT-PCR commercial kit. Briefly, $2 \mu \mathrm{L}$ of the first-strand product was used as a template for amplification in a $50 \mu \mathrm{L}$ reaction mixture containing $20 \mathrm{pmol}$ of primers and $1.6 \mathrm{mM}$ $\mathrm{MgCl}_{2}$. All PCR conditions were the same as described above, but the amount of RT-Taq DNA polymerase platinum enzymes was calculated to 2.5 units $/ 50 \mu \mathrm{L}$ reaction mixture. A total of $10 \mu \mathrm{L}$ of PCR products was electrophoresed at $100 \mathrm{~V}$ for $1 \mathrm{~h}$ using a $1.5 \%$ agarose gel in Tris-borate EDTA buffer and visualized with ethidium bromide staining and an ultraviolet transluminator. Gel images were captured using a Kodak DC290 digital camera and ADOBE 6.0 software.

\section{DNA sequencing and phylogenetic analysis}

The PCR products were purified using a commercial purification kit (QIAquick PCR purification kit; Qiagen) according to the manufacturer's instructions and sequenced directly with an ABI 3730xl DNA analyzer (Applied Biosystems). Nucleotide sequences derived from this study have been deposited in the GenBank sequence database under the following accession numbers: GU323504, Agamia/BR/ UNESP/2009; GU323505, APatagonius/BR/UNESP/2009; GU323506, Pavus/BR/UNESP/2009; GU323507, Pavus/2/ BR/UNESP/2009; GU323508, Penelope/BR/UNESP/2009; 


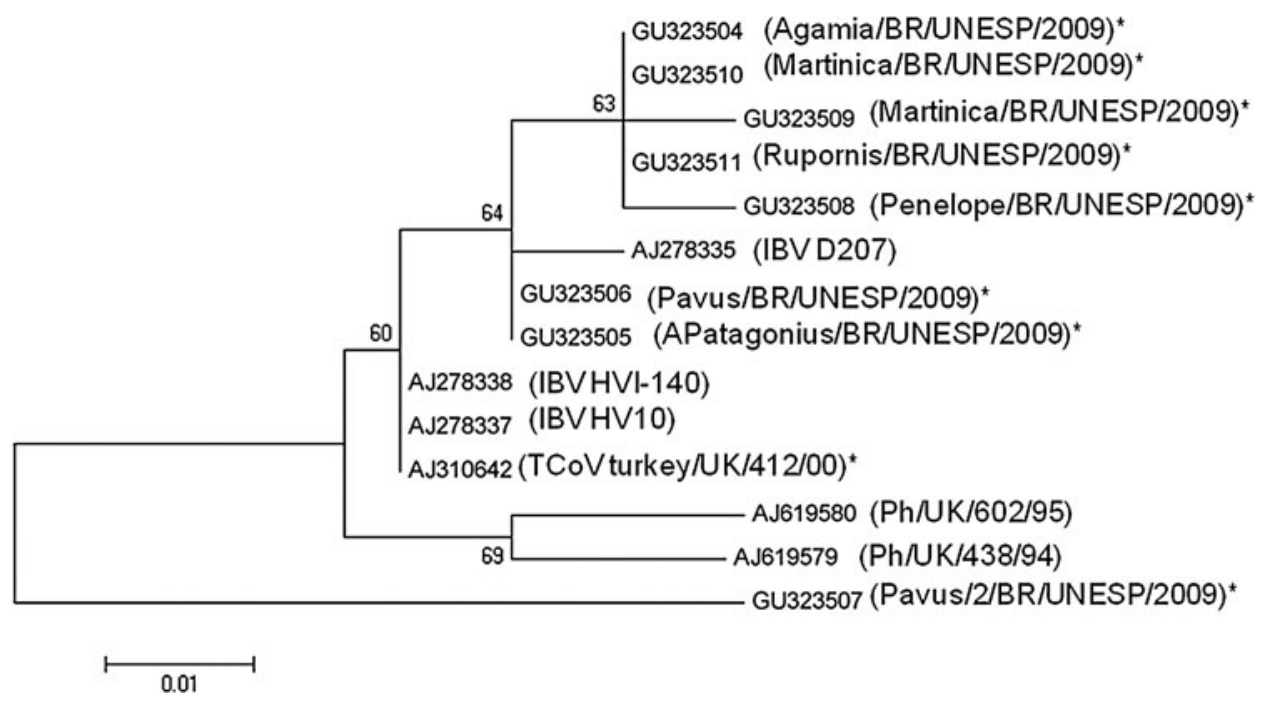

FIG. 1. Minimum-evolution tree of coronaviruses (CoVs) based on a 146-nt fragment of the $3^{\prime}$ untranslated region from group $3 \mathrm{CoVs}$. Evolutionary distances were computed using the Tamura-Nei method and are expressed as the number of base substitutions per site. CoVs detected in captive wild birds by this study are denoted with an asterisk. Previously published $\mathrm{CoV}$ sequences from different sources were included for comparative purposes. GenBank accession numbers are shown in brackets. The percentage of replicate trees in which the associated taxa clustered together in the bootstrap test (1000 replicates) is shown next to the branches. Phylogenetic analyses were conducted in MEGA4. The scale bar indicates nucleotide substitutions per site.

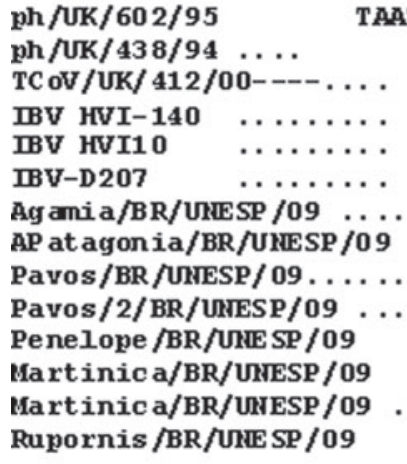

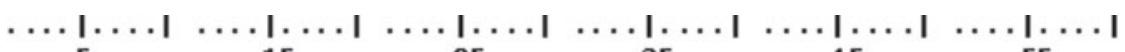
515
35
45
55

25

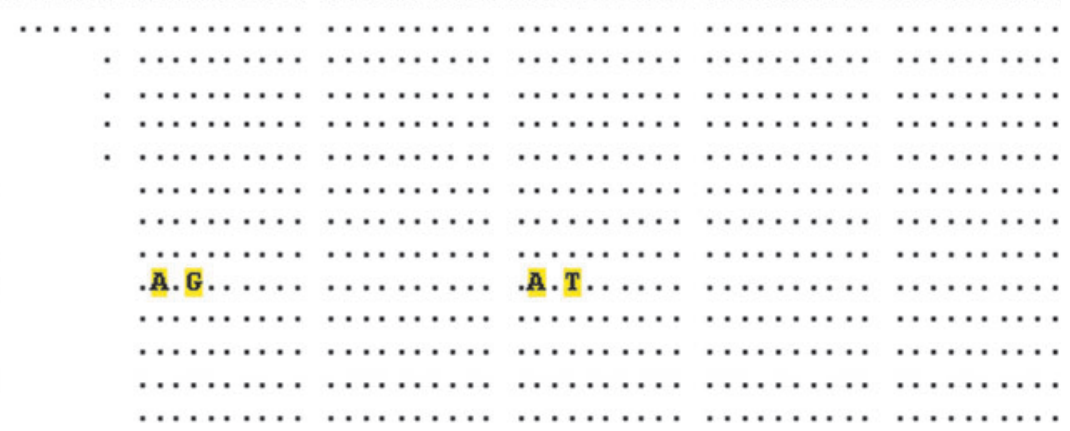

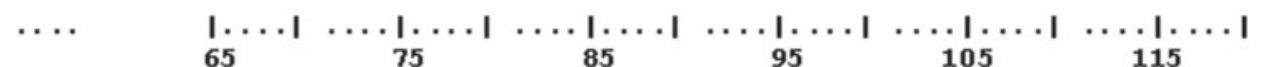

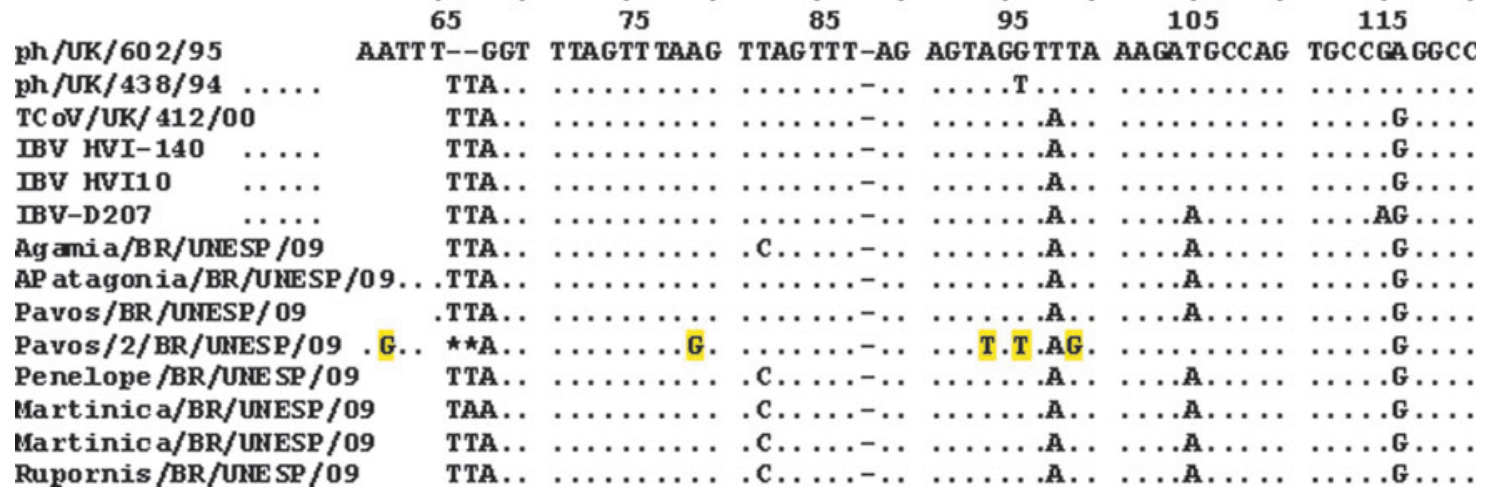

FIG. 2. A comparison of part of the $3^{\prime}$ untranslated region from three CoVs isolated from chickens (prefixed IBV), one CoV from turkeys (prefixed TCoV), and two CoVs from pheasants (prefixed ph), with the same region identified in the eight CoVs isolated from the captive birds described in this study. Dots indicate that all the viruses had the same nucleotide at that position. Deletions are marked with an asterisk. Yellow shading indicates the mutations observed in the Pavus/2/BR/ UNESP/09 sequence at a given position. 
GU323510, Martinica/BR/UNESP/2009; GU323509, Martinica/BR/UNESP/2009. The CoV sequences AJ619580 (pheasant CoV ph/UK/602/95), AJ619579 (pheasant CoV ph/UK/438/94), AJ310642 (Turkey CoV turkey/UK/412/ 00), AJ278338 (IBV HVI-140), AJ278337 (IBV HV10), and AJ278335 (IBV D207) were obtained from GenBank for use in the phylogenetic analyses. Sequences were assembled using SeqMan Pro., and genome annotation was conducted with SeqBuilder (DNASTAR, Inc., v.8.0.2). Nucleotide and deduced amino acid sequences were aligned using Clustal- $W$ in the MegAlign program (DNASTAR, Inc.). A phylogenetic tree was constructed based on amino acid alignments using BLASTN analysis (www.blast.ncib.nlm.nih.gov/Blast.cgi).

\section{Results and Discussion}

Captive animals in zoos are part of a complex ecosystem that includes free-roaming animals and their associated infectious diseases, including respiratory viruses. These results, obtained from captive birds in Brazil, represent the first report of a circulating $\mathrm{CoV}$ inside a zoological park. The CoV RNA was detected in eight individual fecal samples (Table 1), which corresponds to an individual prevalence estimate of $1.12 \%$ (95\% confidence interval $0.5-2.7$ ). Of the samples considered positive, two were from black shouldered peafowl (Pavus cristatus), two were from American purple gallinules (Porhyrula martinica), and one each came from a Chestnut-bellied heron (Agamia agamia), an Emperor penguin (Aptenodytes patagonicus), a Rusted margined guan (Penelope supercilliaris), and a Roadside hawk (Rupornis magnirostris). Interestingly, all of the positive samples were obtained from adult birds. Phylogenetic analyses were based on a sequence of $146 \mathrm{nt}$ after the removal of primer sites (Fig. 1). Most remarkably, nine mutations were revealed in the Pavus/2/BR/ 2009 (GU323507) sequence, despite many reports that consider the $3^{\prime}$ UTR region to be highly conserved among group 3 CoVs (Cavanagh et al. 2002). One hypothesis that could explain these mutations is the high density of different species of birds located in the same geographical area, which allows the virus to circulate among species (Jackwood et al. 2010). On the other hand, the natural habitat provides more distance between species, particularly between predators and prey. In addition, the sequences of the CoVs isolated from the two peafowl samples clustered separately from the British deposited sequences, as illustrated in Figure 1 (Cavanagh et al. 2002). Sequences within this cluster were relatively homogenous between two European samples (Fig. 1), in accordance with previous studies (Cavanagh et al. 2002).

Samples obtained from the Chestnut-bellied heron, two American purple gallinules, a Roadside hawk, and a rusted margined guan clustered together in a single clade, close to the sequence of the IBV D 207 strain (Figs. 1 and 2). In the present study of samples collected from 25 different species (kept in isolated locations within the zoological park), $\mathrm{CoV}$ RNA was detected in two Galliformes, two Ciconiiformes, one Gruiforme, and one Sphenisciforme. This demonstrates the high diversity in the susceptible species, as described previously (Woo et al. 2008). In fact, CoVs have been also detected in wildfowl species, rock doves, wild peafowl, waders, Amazon parrots, and some passerine species (Cavanagh 2005, Liu et al. 2005, Gough et al. 2006, Woo et al. 2008,
Hughes et al. 2009). The hypothesis that wild free-flying birds present in zoos may often act as vectors flying between enclosures that house the exotic birds and transmitting infections is not fully understood.

To understand the potential role of captive populations as reservoirs for CoVs, further studies are needed not only in South American zoo parks, but also worldwide. This is the first description of the molecular detection of group $3 \mathrm{CoVs}$ related to captive birds in South America. The genetic diversity found in the black shouldered peafowl samples raises interesting questions about the $3^{\prime}$ UTR conserved region, its evolution, and viral circulation among different species inside zoo parks.

\section{Acknowledgments}

This work was supported by FAPESP (Fundação Amparo à Pesquisa do Estado de São Paulo) and CNPq. The authors are indebted to the technical team of the zoological park for their support. Tereza Cristina Cardoso is a recipient of CNPq grant.

\section{Disclosure Statement}

No competing interests exist.

\section{References}

Adzar, A, Gough, RE, Haydon, D, Shaw, K, et al. Molecular analysis of the 793/B serotype of infectious bronchitis virus in Great Britain. Avian Pathol 1997; 86:625-640.

Cavanaugh, D. Coronaviruses in poultry and other birds. Avian Pathol 2005; 34:439-448.

Cavanagh, D, Mawditt, K, Welchman Dde, B, Britton, P, Gough, RE. Coronaviruses from pheasants (Phasianus colchicus) are genetically closely related to coronaviruses of domestic fowl (infectious bronchitis virus) and turkeys. Avian Pathol 2002; 31:81-93.

Culver, F, Dziva, F, Cavanagh, D, Stevens, MP. Poult enteritis and mortality syndrome in turkeys in Great Britain. Vet Rec 2006; 159:209-210.

Gough, RE, Drury, SE, Culver, F, Britton, P, Cavanagh, D. Isolation of a coronavirus from a green-cheeked Amazon parrot (Amazon viridigenalis Cassin). Avian Pathol 2006; 35: 122-126.

Hughes, LA, Savage, C, Naylor, C, Bennett, M, et al. Genetically diverse coronaviruses in wild bird populations of Northern England. Emerg Infect Dis 2009; 15:1091-1094.

Jackwood, MW, Boynton, TO, Hilt, DA, McKinley, ET, et al. Emergence of a group 3 coronavirus through recombination. Virology 2010; 398:98-108.

Teixeira, MC, Luvizotto, MC, Ferrari, HF, Mendes, AR, et al. Detection of turkey coronavirus in commercial turkey poults in Brazil. Avian Pathol 2007; 36:29-33.

Woo, PC, Lau, SK, Lam, CS, Lai, KK, et al. Comparative analysis of complete genome sequences of three avian coronaviruses reveals a novel group 3c coronavirus. J Virol 2008; 83:908-917.

Address correspondence to: Tereza C. Cardoso

Laboratory of Animal Virology UNESP, School of Veterinary Medicine University of São Paulo State, Araçatuba Brazil

E-mail: tcardoso@fmva.unesp.br 